Fadhilah, et al/Jurnal Ekonomi Syariah Teori dan Terapan Vol. 6 No. 2 Februari 2019: 305-318; IMPLEMENTASI PERAN KOPERASI DALAM PEMBERDAYAAN DAN KEMANDIRIAN PONDOK (STUDI KASUS PADA PONDOK PESANTREN MUKMIN MANDIRI SIDOARJO)

\title{
IMPLEMENTASI PERAN KOPERASI DALAM PEMBERDAYAAN DAN KEMANDIRIAN PONDOK (STUDI KASUS PADA PONDOK PESANTREN MUKMIN MANDIRI SIDOARJO)
}

\author{
Yunan Fadhilah \\ Departemen Ekonomi Syariah-Fakultas Ekonomi dan Bisnis-Universitas Airlangga \\ Email: yunan.fadhilah@yahoo.com \\ Irham Zaki \\ Departemen Ekonomi Syariah-Fakultas Ekonomi dan Bisnis-Universitas Airlangga \\ Email: irhamzaki@yahool.com
}

\begin{abstract}
:
The purpose of the study was to find out the role of Pesantren Mukmin Mandiri Cooperative Sidoarjo towards economic empowerment and independence of employee boarding schools. The research method used is a descriptive qualitative approach to the case study method. Primary data collection was carried out by interviews and direct observation of informants, namely those in charge of pesantren, cooperative and cooperative employees (santri). Furthermore, secondary data collection comes from journals, textbooks and other literature. The result of this study shows that Pesantren Mukmin Mandiri Cooperative plays a major role in enhancing the empowerment of cooperative employees (santri) and playing an optimal role in supporting the independence of the Islamic boarding school. The economic empowerment of pesantren employees conducted by the Pesantren Mukmin Mandiri Cooperative is by making the Cooperative as a work field, a place to apply knowledge and earn additional income. As for the independence of the Islamic boarding school, the Cooperative becomes the main source of funding for Islamic boarding schools in carrying out operations and the sustainability of Islamic boarding schools. Going forward, the Cooperative will further optimize the empowerment of union employees (santri) to produce santri equipped with entrepreneurship skills and a good comprehension of religion.
\end{abstract}

Keywords: Cooperative Boarding School, Economic Empowerment, Independence of Islamic Boarding Schools.

\section{PENDAHULUAN}

Perkembangan pendidikan di

Indonesia ditandai dengan kemunculan berbagai lembaga pendidikan, salah satunya adalah kemunculan lembaga pendidikan pesantren. Ada berbagai macam bentuk pesantren dari yang tradisional hingga modern. Lembaga pendidikan Islam ini memiliki fungsi dan perannya sesuai dengan tuntutan zaman.

Pesantren sebagai lembaga pendidikan Islam di indonesia memiliki berbagai macam fungsi dan peran. Kebanyakan pesantren di indonesia dipandang sebagai lembaga untuk pendidikan moral dan kereligiusitasan, lembaga untuk berdakwah, dan juga sebagai lembaga sosial ekonomi dimana ada berbagai macam tantangan dalam pengembangan pesantren baik dari dalam (internal) maupun dari luar (eksternal).

Zuhriy (2011) menjelaskan bahwa pesantren adalah sub-kultur tersendiri dikarenakan ciri-ciri yang dimiliki pondok pesantren tidak ditemukan ditempat lain, ciri-ciri yang khas yang disebutkan Gus Dur tersebut adalah sebagai berikut : adanya tokoh agama (kiai atau ustad), memiliki santri, memiliki masjid, adanya tempat

1) Jurnal ini merupakan bagian dari skripsi Yunan Fadhilah, NIM: 041411433050, yang diuji pada tanggal 23 Oktober 2018. 
Fadhilah, et al/Jurnal Ekonomi Syariah Teori dan Terapan Vol. 6 No. 2 Februari 2019: 305-318; IMPLEMENTASI PERAN KOPERASI DALAM PEMBERDAYAAN DAN KEMANDIRIAN PONDOK (STUDI KASUS PADA PONDOK PESANTREN MUKMIN MANDIRI SIDOARJO)

tinggal (pondok), dan melakukan pengajaran kitab klasik. Pesantren dikatakan sebagai sub-kultur dikarenakan adanya faktor pendukung lain seperti, pola kepemimpinan yang mandiri tidak bergantung kepada negara,kitab-kitab rujukan yang dikaji berasal dari kitab klasik yang disebut kitab kuning, serta sistem nilai yang dipilih.

Seiring dengan perkembangan zaman pesantren tidak hanya mengajarkan tentang pendidikan formal saja tetapi juga non formal. Menurut Saridjo dalam Sanin (2008:45) menyatakan bahwa pondok pesantren telah mengalami lima fase perkembangan yaitu: Pertama, dijelaskan bahwa pondok pesantren yang hanya terdiri dari masjid dan rumah kiai. Pondok pesantren seperti ini masih bersifat sederhana sekali, di mana kiai masih mempergunakannya untuk tempat mengajar, kemudian santri hanya datang dari daerah sekitar pesantren itu sendiri. Kedua, Pondok Pesantren selain masjid dan rumah kiai, juga telah memiliki pondok atau asrama tempat menginap para santri yang datang dari daerah-daerah yang jauh. Ketiga, Pondok Pesantren yang di samping memiliki kedua pola tersebut di atas dengan sistem weton dan sorogan, juga telah menyelenggarakan sistem pendidikan formal seperti madrasah. Keempat, Pondok Pesantren yang selain memiliki komponen-komponen fisik seperti (mesjid dan asrama), pesantren juga memiliki sarana sebagai suatu tempat pendidikan keterampilan seperti peternakan, pertukangan, sawah/ladang, koperasi dan sebagainya, koperasi merupakan salah satu dari tanda perkembangan sebuah pesantren. Kelima, Pondok Pesantren yang memiliki pola keempat tersebut, ataupun dengan bangunan-bangunan seperti perpustakaan, dapur umum, ruang makan, kantor administrasi, toko, dan lain sebagainya. Pondok pesantren tersebut telah berkembang atau bisa juga disebut pondok pesantren pembangunan.

Koperasi Pondok Pesantren merupakan salah satu organisasi pemberdayaan ekonomi yang berada di pondok pesantren dalam upaya meningkatkan kesejahteraan, baik di lingkungan pesantren maupun di lingkungan masyarakat luar, dengan mengoptimalkan penggunaan sumber daya yang ada pada lingkungan sekitar pesantren sehingga memberikan dampak positif dengan terbentuknya usaha-usaha baru yang menguntungkan. Usaha-usaha yang telah terbentuk yang dikelola pesantren dan dapat memberikan keuntungan ekonomi pada santri dan pesantren. Melalui koperasi, aktifitas perekonomian Pesantren bisa terwadahi. Adanya wadah Koperasi ini, diharapkan sebagai tempat untuk mengembangkan diri, dan menambah keterampilan dalam berbagai hal serta memperluas pengalaman. Sehingga organisasi ini berdampak positif bagi anggotanya misalnya menambah pengetahuan dibidang kewirausahaan yang dapat berguna dalam kehidupan sehari-hari. 
Fadhilah, et al/Jurnal Ekonomi Syariah Teori dan Terapan Vol. 6 No. 2 Februari 2019: 305-318; IMPLEMENTASI PERAN KOPERASI DALAM PEMBERDAYAAN DAN KEMANDIRIAN PONDOK (STUDI KASUS PADA PONDOK PESANTREN MUKMIN MANDIRI SIDOARJO)

Produk dari Koperasi Mukmin Mandiri sudah berhasil menembus pasar Internasional, pemasaran kopi Mahkota Raja telah mencapai beberapa negara di Asia, khususnya Malaysia dan Dubai. Jika dihitung berdasarkan mata vang Indonesia, harga perkilo kopi mencapai Rp 70 ribu. Bahkan kopi Mahkota Raja sedang mencoba menjajaki pasar Eropa. produk kopi doa ini tergolong langka di kalangan komunitas perkopian Indonesia. Bukan hal yang mengagetkan jika penjualan produk ini mencapai 35-45 ton per bulannya. Proses ini dikerjakan oleh 300-400 santri. Volume yang cukup mengejutkan untuk pesantren yang baru memulai bisnis kopi. Rata-rata kopi dijual di pasar lokal dengan harga Rp 30 ribu (biji sangrai dan bubuk). Total pendapatan mencapai 1 miliar tiap tahunnya. Respon masyarakat sangat bagus. Pendapatan dari produksi kopi Mahkota Raja milik Koperasi Mukmin Mandiri dipergunakan untuk pemberdayaan dan kemandirian santri dan Pondok Pesantren.

Berdasarkan latar belakang diatas, rumusan masalah dalam penelitian ini adalah bagaiman implementasi peran koperasi dalam pemberdayaan dan kemandirian pondok pesantren Mukmin Mandirie Dan tujuan penelitian ini adalah mengetahui peran apa saja yang diberikan koperasi dalam pemberdayaan dan kemandirian pondok.

\section{LANDASAN TEORI}

Tujuan pesantren dalam mendidik santri adalah untuk menciptakan insan yang berakhlak mulia dan beriman dan bertaqwa pada Tuhan, bermanfaat bagi masyarakat, untuk mempersiapkan pemimpin-pemimpin yang berakhlaq dan beragama. Diharapkan bahwa para santri akan pulang ke masyarakat mereka sendiri untuk menjadi pimpinan yang tidak resmi dari masyarakatnya. Para santri di dalam pesantren di ajari tentang bagaimana memperdalam pengetahuan tentang Al-Qur'an dan Sunnah Rasul, dengan mempelajari bahasa Arab dan kaidah-kaidah tata bahasa Arab. Sebagai institusi sosial, pesantren memiliki peranan yang penting dalam beberapa negara, khususnya beberapa negara yang banyak pemeluk agama Islam di dalamnya. Pesantren mengajarkan tentang nilai-nilai kesederhanaan, keikhlasan, kemandirian, dan pengendalian diri. Para santri dipisahkan dari orang tua dan keluarga mereka, agar dapat meningkatkan hubungan dengan kyai dan juga Tuhan.

Djumransjah (2001:144) mengatan bahwa pesantren yang ada di nusantara ini secara substansial memiliki misi-misi. Misi-misi itu dapat diidentefikasikan sebagai misi ibadah, misi tabligh, dan misi amal. Temuan penelitian ini mengandung makna bahwa pesantren sebagai lembaga pendidikan jalur luar sekolah telah memadukan 3 unsur pendidikan yang sangat penting yaitu ibadah untuk menanamkan iman, tabligh untuk penyebaran ilmu, dan amal untuk mewujudkan kegiatan kemasyarakatan dan dalam kehidupan sehari-hari. Dari sini 
Fadhilah, et al/Jurnal Ekonomi Syariah Teori dan Terapan Vol. 6 No. 2 Februari 2019: 305-318; IMPLEMENTASI PERAN KOPERASI DALAM PEMBERDAYAAN DAN KEMANDIRIAN PONDOK (STUDI KASUS PADA PONDOK PESANTREN MUKMIN MANDIRI SIDOARJO)

dapat dipahami bahwa Tri Dharma Pondok Pesantren yang meliputi keimanan dan ketaqwaan terhadap Allah Subhanahu Wata'ala, pengembangan ilmu yang bermanfaat, dan pengabdian terhadap agama, masyarakat dan negara telah dijalankan di dalam pondok pesantren.

Azyumardi (1997: 1) menjelaskan tumbuhnya gerakan koperasi di kalangan santri merupakan salah satu bentuk perwujudan dari konsep saling menolong (ta'awun), persaudaraan (ukhuwah), menuntut ilmu (tholabul ilmi) dan berbagai aspek ajaran Islam lainnya. Konsep bersama-sama (berjaa'ah) dan dijalankan secara hukum yang jelas dan adil (syariah) yang relevan dengan tujuan koperasi didirikan, dikelola dengan ketentuan peraturan bersama dan kesejahteraan untuk anggota secara menyeluruh.

Koperasi pondok pesantren adalah pondok pesantren yang memiliki badan usaha yang berbentuk koperasi dan angota-anggotanya merupakan para santri yang berada dalam pesantren maupun masyarakat luar di sekitar pesantren. Secara organisasi koperasi pondok pesantren tidak hanya organisasi yang menggunakan sistem ekonomi sosial tetapi juga mempunyai unsur religi yang di implementasikan dalam kegiatankegiatan individu (anggota) yang bertekat untuk memperbaiki situasi ekonomi dan sosial mereka, melalui usaha-usaha bersama saling membentu dan amanah yang berdasarkan akidah- akidah agama untuk kepentingan bersama.

pemberdayaan ekonomi rakyat adalah upaya yang mengerahkan sumberdaya untuk mengembangkan potensi ekonomi ekonomi rakyat untuk meningkatkan produktifitas rakyat sehingga, baik sumber daya manusia maupun sumber daya alam di sekitar keberadaan rakyat, dapat ditingkatkan produktifitasnya. Berbagai pandangan mengenai konsep pemberdayaan maka dapat disimpulkan bahwa permberdayaan ekonomi masyarakat adalah penguatan pemilikan faktor-faktor produksi, penguatan penguasaan distribusi dan pemasaran, penguatan masyarakat untuk mendapatkan gaji yang memadai, dan penguatan masyarakat untuk memperoleh informasi, pengetahuan dan ketrampilan, yang harus dilakukan secara multi aspek, baik dari aspek masyarakatnya sendiri, maupun aspek kebijakannya.

Sumodiningrat dalam Hutomo (2000:6) menjelaskan secara ringkas tentang pemberdayaan ekonomi rakyat yaitu sebagai berikut:

1. Perekonomian rakyat adalah perekonomian yang diselenggarakan oleh rakyat. Perekonomian yang diselenggarakan oleh rakyat adalah perekonomian nasional yang berakar pada potensi dan kekuatan masyarakat secara luas untuk menjalankan roda perekonomian mereka sendiri. 
Fadhilah, et al/Jurnal Ekonomi Syariah Teori dan Terapan Vol. 6 No. 2 Februari 2019: 305-318; IMPLEMENTASI PERAN KOPERASI DALAM PEMBERDAYAAN DAN KEMANDIRIAN PONDOK (STUDI KASUS PADA PONDOK PESANTREN MUKMIN MANDIRI SIDOARJO)

2. Pemberdayaan ekonomi rakyat adalah usaha untuk menjadikan ekonomi yang kuat, besar, modern, dan berdaya saing tinggi dalam mekanisme pasar yang benar. Karena kendala pengembangan ekonomi rakyat adalah kendala struktural, maka pemberdayaan ekonomi rakyat harus dilakukan melalui perubahan struktural.

3. Perubahan struktural yang dimaksud adalah perubahan dari ekonomi tradisional ke ekonomi modern, dari ekonomi lemah ke ekonomi kuat, dari ekonomi subsisten ke ekonomi pasar, dari ketergantungan ke kemandirian. Langkah-langkah proses perubahan struktur, meliputi: pengalokasian sumber pemberdayaan sumber daya, penguatan kelembagaan, penguasaan teknologi.

4. Pemberdayaan ekonomi rakyat, tidak cukup hanya dengan peningkatan produktivitas, memberikan kesempatan berusaha yang sama, dan hanya memberikan suntikan modal sebagai stumulan, tetapi harus dijamin adanya kerjasama dan kemitraan yang erat antara yang telah maju dengan yang masih lemah dan belum berkembang.

5. Kegiatan pemberdayaan yang mencakup: peningkatan akses bantuan modal usaha, peningkatan akses pengembangan SDM, peningkatan akses ke sarana dan prasarana yang mendukung sosial ekonomi masyarakat lokal.

Perekonomian di Indonesia masih memiliki banyak permasalahan dan memerlukan banyak upaya untuk keluar dari permasalahan ekonomi ini, diperlukan perjuangan besar dan komitmen dari setiap komponen masyarakat pribadi, untuk umat Muslim sendiri dalam rangka meningkatkan perekonomian ditantang untuk lebih keras dalam bekerja, berkreasi, dan berwirausaha, lebih-lebih dalam bekerja sama komunikatif dalam berintaksi, lebih terampil, dan lebih profesional dalam mengelola potensi dan kekuatan ekonomi umat di sektor riil. Agar dapat terlepas dari perekonomian yang seperti saat ini, di samping keterampilan hidup, keterampilan berwirausaha, dibutuhkan juga pengembangan dan pemberdayaan ekonomi kerakyatan, yang selama ini kurang kita perhatikan.

$$
\text { Menurut Rosyidi }
$$
Pemenuhan kebutuhan primer (sandang, pangan, papan) terletak pada urutan pertama. Kebutuhan primer di dalam fungsi konsumsi terletak paling bawah dan di atasnya kemudian menyusul kebutuhan-kebutuhan dari tingkat selanjutnya, seperti kebutuhan akan kendaraan, pendidikan, pengobatan, dan sebagainya.

$$
\text { Menurut Burnadib dalam Muttaqin }
$$

(2011) kemandirian merupakan suatu keadaan ketika seseorang memiliki hasrat 
Fadhilah, et al/Jurnal Ekonomi Syariah Teori dan Terapan Vol. 6 No. 2 Februari 2019: 305-318; IMPLEMENTASI PERAN KOPERASI DALAM PEMBERDAYAAN DAN KEMANDIRIAN PONDOK (STUDI KASUS PADA PONDOK PESANTREN MUKMIN MANDIRI SIDOARJO)

bersaing untuk maju demi kebaikan dirinya, mampu mengambil keputusan dan inisiatif untuk mengatasi masalah yang dihadapi, memiliki kepercayaan diri dalam mengerjakan tugas-tugasnya, dan bertanggung jawab terhadap apa yang dilakukannya.

Menurut Solichin (2012) pokokpokok kemandirian pesantren dapat dikelompokkan dalam tiga hal, yaitu:

1. Kemandirian dalam bidang pendidikan adalah dalam merumuskan kurikulum pendidikan pesantren, sepenuhnya dirumuskan sendiri, dan tidak terpengaruh dengan tekanan pemerintah dan negara. Semuanya tetap berfokus pada kurikulum kajian kitab klasik. Dengan demikian pesantren memiliki kemandirian pendidian yang sangat kokoh, suatu prinsip yang sebenarnya harus dimiliki pesantren secara universal.

2. Kemandirian pesantren di bidang ekonomi berkaitan dengan kegiatan usaha pesantren dalam membangun kemandirian ekonomi seperti ritel, usaha percetakan, koperasi, home industry dan lain-lain.

3. Kemandirian pesantren di bidang politik yaitu komitmen pesantren untuk berdiri di atas semua golongan, tidak berpihak pada partai politik manapun. Apabila ada unsur pesantren termasuk alumnni yang mencalonkan diri di salah satu parpol maka harus melepas jabatan yang ada di pesantren dan harus tinggal di luar pesantren.

\section{METODE PENELITIAN}

Penelitian menggunakan metode kualitatif deskriptif studi kasus karena penelitian ini membutuhkan keterangan dan gambaran secara komprehensif, aktual, dan faktual mengenai implementasi peran koperasi dalam pemberdayaan dan kemandirian pondok Pesantren Mukmin Mandiri Sidoarjo.

Yin (2015:29) menyatakan untuk studi kasus ada lima komponen desain penelitian yang sangat penting, yaitu :

1. Pertanyaan Penelitian

Pertanyaan penelitian berkenaan dengan: "siapa", "apa", "di mana", "bagaimana", dan "mengapa" memberi rambu-rambu terhadap strategi penelitian yang akan digunakan, strategi studi kasus merupakan strategi yang cocok untuk pertanyaanpertanyaan "bagaimana", dan "mengapa", sehingga tugas pertama peneliti studi kasus adalah mengklarifikasikan pertanyaan-pertanyaan yang digunakan dalam penelitian ini. Dalam penelitian ini peneliti menggunakan pertanyaan "bagaimana" sebagai dasar penelitian.

2. Proposisi

Proposisi penelitian akan mengarahkan perhatian peneliti kepada sesuatu yang harus diselidiki 
Fadhilah, et al/Jurnal Ekonomi Syariah Teori dan Terapan Vol. 6 No. 2 Februari 2019: 305-318; IMPLEMENTASI PERAN KOPERASI DALAM PEMBERDAYAAN DAN KEMANDIRIAN PONDOK (STUDI KASUS PADA PONDOK PESANTREN MUKMIN MANDIRI SIDOARJO)

dalam ruang lingkup studinya, juga mengarahkan kepada peneliti dalam mencari bukti yang relevan. Proposisi dari penelitian ini adalah dengan adanya koperasi dalam pondok pesantren Mukmin Mandiri dapat meningkatkan pemberdayaan dan kemandirian pondok.

3. Unit Analisis

Unit analisis merupakan komponen yang secara fundamental berkaitaan dengan masalah penentuan kasus dalam penelitian yang bersangkutan. Unit Analisis dalam penelitian ini yang pertama koperasi pesantren Mukmin Mandiri sebagai tempat produksi, yang kedua para pelaku yaitu pengelola koperasi dan para santri pondok pesantren.

4. Logika yang Mengaitkan Data dengan Proposisi

Komponen ini mengetengahkan tahap analisis data dalam penelitian studi kasus, dan desain penelitian perlu meletakkan dasar-dasar bagi analissi ini. Pengaitan dta terhadap proposisi dapat dilakukan dengan pendekatan yang memberi harapan kepada studi kasus atau disebut penjodohan pola.

5. Kriteria untuk Menginterpretasi Temuan

Kriteria untuk menginterpretasikan temuan masih tidak ada satupun cara yang tepat untu menyusun kriteria guna menginterpretasikan tipe-tipe temuan. Komponen kelima ini dapat dilakukan dengan membandingkan

sekurangkurangnya dua proposisi yang bersaing, diharapkan agar pola- pola yang berbeda tersebut memberi gambaran yang cukup jelas.

Jenis data yang digunakan pada penelitian ini yaitu data primer dan data sekunder.

1. Data Primer

Menurut Umar (2003 : 56), data primer merupakan data yang diperoleh langsung di lapangan oleh peneliti sebagai obyek penulisan. Pada penelitian ini data primer didapatkan dari observasi, wawancara, dan dokumentasi. Observasi dibutuhkan untuk melihat kondisi lapangan secara langsung dan wawancara dibutuhkan untuk memperoleh data yang akurat melalui narasumber yang terdiri dari pelaku industri pengolahan Kopi Mahkota Raja serta warga sekitar Pesantren Mukmin Mandiri

2. Data Sekunder

Menurut Sugiyono (2012 : 62), data sekunder adalah data yang tidak langsung memberikan data kepada peneliti, misalnya penelitian harus melalui orang lain atau mencari melalui dokumen. Data tersebut diperoleh melalui studi kepustakaan seperti bukubuku literatur, buku diktat dan jurnal-jurnal dari berbagai sumber yang terkait dengan penelitian 
Fadhilah, et al/Jurnal Ekonomi Syariah Teori dan Terapan Vol. 6 No. 2 Februari 2019: 305-318; IMPLEMENTASI PERAN KOPERASI DALAM PEMBERDAYAAN DAN KEMANDIRIAN PONDOK (STUDI KASUS PADA PONDOK PESANTREN MUKMIN MANDIRI SIDOARJO)

serta

penelitian-penelitian

terdahulu.

Jenis data yang digunakan dalam penelitian ini adalah kualitatif dan kuantitatif. Data yang termasuk data kualitatif dalam penelitian ini meliputi: Sejarah singkat berdirinya lokasi penelitian, letak geografis obyek, Visi dan Misi, struktur organisasi, keadaan sarana dan prasarana, dll. Data yang termasuk data kuantitatif: Rekapitulasi kuesioner perbandingan berpasangan dan hasil penghitungan supermatriks.

Sumber data penelitian ini digolongkan sebagai data primer dan data sekunder. Data primer adalah data yang didapatkan secara langsung (firsthand), data dalam penelitian ini berasal dari key informan (informan kunci). Data sekunder adalah data tambahan atau penunjang yang digunakanpeneliti sebagai pendukung data penelitian. Data ini diperoleh melalui studi literatur yang banyak dan mendalam, literatur yang dipakai bisa berupa jurnal penelitian, buku, artikel, situs web yang berkaitan.

Teknik pengumpulan data meliputi: survey pendahuluan, penelitian di loaksi atau lapangan, dan pengumpulan data. Penelitian ini menggunakan teknik analisis pembuatan penjelasan (naratif-deskriptif) wawancara, observasi dan dokumentasi.

Teknik pengolahan data wawancara meliputi: reduksi data, penyajian data, menarik kesimpulan atau verifikasi.

\section{HASIL DAN PEMBAHASAN}

\section{ANALISIS HASIL WAWANCARA}

\begin{tabular}{ccc}
\multicolumn{2}{c}{ Koperasi Mukmin } & Mandiri \\
merupakan salah satu binaan
\end{tabular} Cooperative Trading House (CTH) Jawa Timur yang dibentuk Dinkop dan UMKM Jatim. Aktivitas $\mathrm{CTH}$ adalah memfasilitasi koperasi agar mampu memperluas penjualan produk yang dihasilkannya, baik di pasar domestik maupun ekspor. Peluncuran ekspor kopi pertama kali ditandai dengan pemberangkatan truk kontainer dari halaman kantor Dinas Koperasi dan Usaha Mikro Kecil dan Menengah (Dinkop dan UMKM) Jawa Timur menuju pelabuhan Tanjung Perak, Surabaya, dan di berangkatkan oleh Kepala Dinkop dan UMKM Jatim I Made Sukartha.

Jika dilihat dari AD/ART yang di berikan oleh pihak koperasi, Koperasi bertujuan memajukan kesejahteraan anggota pada khususnya dan masyarakat pada umumnya serta ikut membangun tatanan perekonomian nasional dalam rangka mewujudkan masyarakat adil dan makmur berdasarkan Pancasila dan Undang-undang Dasar 1945 dengan kegiatan usaha produksi kopi. Anggota Koperasi adalah pemilik dan sekaligus pengguna jasa dari kegiatan usaha yang diselenggarakan Koperasi dimana setiap anggota harus tunduk pada ketentuan dalam Anggaran Dasar dan Aturan Rumah Tangga, Peraturan Khusus dan Keputusan Rapat Anggota. Keanggotaan Koperasi Mukmin Mandiri ini tidak hanya terbatas untuk kalangan Pesantren saja, apabila ada pihak luar yang ingin menjadi anggota 
Fadhilah, et al/Jurnal Ekonomi Syariah Teori dan Terapan Vol. 6 No. 2 Februari 2019: 305-318; IMPLEMENTASI PERAN KOPERASI DALAM PEMBERDAYAAN DAN KEMANDIRIAN PONDOK (STUDI KASUS PADA PONDOK PESANTREN MUKMIN MANDIRI SIDOARJO)

Koperasi akan di perbolehkan dengan mematuhi ketentuan yang berlaku. Keanggotaan tidak dapat dipindah tangankan kepada siapapun dengan cara apapun (Hasil wawancara 20 September 2018).

Tujuan didirikannya koperasi ini tidak lain adalah untuk menjadi wadah bagi kegiatan wirausaha yang sejak awal telah menjadi visi dan misi dari pesantren Mukmin Mandiri, tujuan didirikannya koperasi ini juga agar kelak di masa depan ketika santri lulus bisa mandiri dengan ilmu yang di dapat pada saat belajar dan berwirausaha di koperasi. Dengan visi dan misi yang sudah jelas dan spesifik dalam hal agrobisnis dan agroindustry maka sistem manajerialnya harus dikelola secara modern dan professional.

\section{Pemberdayaan}

$$
\text { Menurut Hutomo (2000: 3) }
$$

pemberdayaan ekonomi masyarakat adalah penguatan pemilikan faktor-faktor produksi, penguatan penguasaan distribusi dan pemasaran, penguatan masyarakat untuk mendapatkan gaji/upah yang memadai, dan penguatan masyarakat untuk memperoleh informasi, pengetahuan dan ketrampilan, yang harus dilakukan secara multi aspek, baik dari aspek masyarakatnya sendiri, mapun aspek kebijakannya.

Setelah peneliti melakukan survey dan wawancara ke tempat penelitian, peneliti menemukan hasil bahwa Koperasi Mukmin Mandiri mampu memberdayakan ekonomi santri. Berdasarkan data dari hasil wawancara yang peneliti lakukan di lapangan, terdapat dua bentuk pemberdayaan yang dilakukan oleh koperasi selama ini, yaitu pertama koperasi berperan sebagai penyedia lapangan pekerjaan bagi santri yang membutuhkan pekerjaan, yang kedua yaitu menjadi tempat untuk menambah income bagi santri yang ingin menambah pendapatannya. Koperasi melibatkan santri di dalam setiap kegiatannya, hal ini merupakan fakta yang menjadi jawaban dari pertanyaan peneliti tentang peran koperasi dalam memberdayakan santri.

Tabel 1.

Program Pemberdayaan oleh Koperasi

\begin{tabular}{|c|c|}
\hline $\begin{array}{c}\text { Program } \\
\text { Pemberdayaan }\end{array}$ & Sasaran \\
\hline $\begin{array}{l}\text { 1. Perekrutan tenaga } \\
\text { kerja }\end{array}$ & $\begin{array}{l}\text { 1. Santri, dengan } \\
\text { memberikan } \\
\text { lapangan kerja }\end{array}$ \\
\hline $\begin{array}{ll}\text { 2. } & \text { Memberikan } \\
\text { pelajaran tentang } \\
\text { kewirausahaan }\end{array}$ & $\begin{array}{l}\text { 2. Santri, dengan } \\
\text { memberikan } \\
\text { materi-materi } \\
\text { kewirausahaan }\end{array}$ \\
\hline $\begin{array}{l}\text { 3. Pelatihan produksi } \\
\text { kopi }\end{array}$ & $\begin{array}{l}\text { 3. Santri, dengan } \\
\text { mengajari } \\
\text { praktek produksi } \\
\text { kopi }\end{array}$ \\
\hline 4. Pelatihan barista & $\begin{array}{l}\text { 4. Santri, dengan } \\
\text { memberikan } \\
\text { pelatihan } \\
\text { barista }\end{array}$ \\
\hline $\begin{array}{l}\text { 5. } \\
\text { Mengikutsertakan } \\
\text { karyawan dalam } \\
\text { event pameran } \\
\text { kopi }\end{array}$ & $\begin{array}{l}\text { 5. Santri, dengan } \\
\text { mengikutkan } \\
\text { santri dalam } \\
\text { kegiatan event } \\
\text { kopi }\end{array}$ \\
\hline
\end{tabular}


Fadhilah, et al/Jurnal Ekonomi Syariah Teori dan Terapan Vol. 6 No. 2 Februari 2019: 305-318; IMPLEMENTASI PERAN KOPERASI DALAM PEMBERDAYAAN DAN KEMANDIRIAN PONDOK (STUDI KASUS PADA PONDOK PESANTREN MUKMIN MANDIRI SIDOARJO)

\begin{tabular}{|l|ll|}
\hline 6. Pelatihan bertani & 6. & Santri, dengan \\
dan merawat kopi & memberikan \\
& \\
& belatihan \\
& kelompok tani \\
\hline
\end{tabular}

Melihat data yang peneliti dapatkan dari infoman mengenai program-program yang dilakukan untuk memberdayakan para santri, Koperasi sudah berperan dalam meningkatkan kualitas sumber daya manusia yang memiliki potensi, berperan dalam meningkatkan keterampilan, mengurangi pengagguran dengan adanya lapangan kerja, serta menambah income para karyawan yang di berdayakan.

Jika pemberdayaan dalam internal pondok sudah sangat maksimal, maka berbanding terbalik dengan masyarakat luar yang bermukim di sekitar pondok. Selama melakukan survey dan wawancara, peneliti menemukan fakta bahwa tidak banyak masyarakat di sekitar pondok yang terlibat dalam kegiatan koperasi. Meskipun koperasi dan pesantren selalu terbuka bagi siapa saja yang ingin bekerja di koperasi, tetapi keterlibatan masyarakat tetap sedikit dan tidak terlalu signifikan. Program pemberdayaan untuk masyarakat sekitar pondok oleh koperasi memang kurang, sejauh ini kerjasama antara koperasi dengan masyarakat sekitar hanya sekedar kerjasama dengan kelompok tani dalam merawat perkebunan kopi milik koperasi. Kerjasama antara koperasi dan kelompok tani ini terjadi di pesantren
Mukmin Mandiri 2 yang terletak di Kabupaten Tulungagung. Hal ini di ungkapkan oleh pihak koperasi yang menjadi narasumber.

Melihat hasil wawancara dan data sekunder yang peneliti dapatkan, peneliti menyimpulkan bahwa koperasi belum mampu memberdayakan masyarakat sekitar pondok secara maksimal, hal ini disebabkan oleh program-program pemberdayaan yang belum jelas dan juga faktor geografis pesantren juga mempengaruhi minimnya pemberdayaan yang dilakukan.

\section{Kemandirian}

Kemandirian Pesantren adalah kemampuaan pesantren untuk memenuhi segala kebutuhan, membangun fasilitas dan menutupi biaya-biaya keseluruhan kegiatan pesantren yang dilakukan untuk mencapai visi dan misi pesantren yang sejak awal sudah menjadi tujuan utama pesantren didirikan. Soedjono (2002 : 30) menyatakan bahwa Pondok Pesantren pada umumnya dalam memenuhi berbagai macam kebutuhan mengembangkan kegiatan ekonominya pada beberapa aspek sebagai berikut:

1. Pembangunan sarana Pesantren

2. Operasional pendidikan

3. Kesejahteraan pengajar

4. Biaya hidup dan biaya belajar santri

5. Pengembangan Pesantren

Dalam mengembangkan Pesantren selama ini Pondok Pesantren Mukmin Mandiri bergantung pada aspek kegiatan ekonomi yang ditopang oleh Koperasi 
Fadhilah, et al/Jurnal Ekonomi Syariah Teori dan Terapan Vol. 6 No. 2 Februari 2019: 305-318; IMPLEMENTASI PERAN KOPERASI DALAM PEMBERDAYAAN DAN KEMANDIRIAN PONDOK (STUDI KASUS PADA PONDOK PESANTREN MUKMIN MANDIRI SIDOARJO)

Mukmin Mandiri, dalam membangun sarana dan prasarana pondok mayoritas dana yang di dapatkan dari keuntungan Koperasi. Setelah peneliti melakukan survey dan wawancara ke tempat penelitian, peneliti menemukan hasil yang menjawab pertanyaan tentang bagaimana peran Koperasi Mukmin Mandiri dalam meningkatkan kemandirian Pondok Pesantren, Pesantren juga bisa dikatakan mandiri tanpa bantuan dari pihak luar.

Pondok Pesantren Mukmin Mandiri sudah mampu membangun sarana pesantren, menutup biaya operasional, mensejahterkan pengajar, biaya hidup dan belajar santri serta mengembangkan pesantren. Hal ini bisa dilakukan karena besarnya peranan Koperasi dalam menopang segala macam kebutuhan pesantren dalam pengembangannya. Peran Koperasi ini terbukti dengan perkembangan Pesantren yang cukup pesat dimana Pesantren Mukmin Mandiri telah memiliki cabang di Kota Tulungagung, pembangunan cabang Pesantren tersebut tidak lepas dari peran Koperasi dalam membantu dana pembangunan. Semua sarana untuk kegiatan belajar dan lainnya di lingkungan Pesantren bisa dikatakan sangat layak dan mencukupi sehingga dalam mengembangkan pesantren bisa dilakukan secara maksimal.
Tabel 2.

Kontibusi Koperasi untuk Kemandirian

Pesantren

\begin{tabular}{|c|c|c|}
\hline \multicolumn{2}{|c|}{ Kontibusi } & Bentuk kontribusi \\
\hline & $\begin{array}{l}\text { Membiayai } \\
\text { dana } \\
\text { operasional } \\
\text { untuk kegiatan } \\
\text { Pondok } \\
\text { Pesantren. }\end{array}$ & $\begin{array}{l}\text { 1. Pembanguna } \\
\mathrm{n} \text { gedung, } \\
\text { perawatan } \\
\text { sarana dan } \\
\text { prasarana. }\end{array}$ \\
\hline 2. & $\begin{array}{l}\text { Mensejahteraka } \\
\mathrm{n} \quad \text { kehidupan } \\
\text { santri. }\end{array}$ & $\begin{array}{l}\text { 2. Memberikan } \\
\text { gaji dan } \\
\text { menggratiskan } \\
\text { fasilitas. }\end{array}$ \\
\hline 3. & $\begin{array}{l}\text { Memberikan } \\
\text { pengalaman } \\
\text { bekerja. }\end{array}$ & $\begin{array}{ll}\text { 3. } & \text { Praktek } \\
& \text { bekerja di } \\
& \text { koperasi }\end{array}$ \\
\hline 4. & $\begin{array}{l}\text { Memberikan } \\
\text { pelajar } \\
\text { wirausaha }\end{array}$ & $\begin{array}{ll}\text { 5. } & \text { Materi } \\
& \text { kewirausahaa } \\
& \text { n dan praktek. }\end{array}$ \\
\hline
\end{tabular}

Jika melihat kontribusi yang diberikan oleh Koperasi dalam meningkatkan kemandirian Pesantren, bisa dikatakan pesantren mampu menjalankan kegiatan operasiomal, dan mengembangkan pesantren dengan menggunakan dana yang diberikan koperasi tanpa bantuan dari pihak luar dimana koperasi sendiri sudah menjadi bagian dari pesantren.

Melihat hasil wawancara dengan beberapa informan beserta data sekunder yang peneliti dapatkan, peneliti dapat menimpulkan bahwa Pesantren sudah bisa dikatakan mandiri karena bisa membangun fasilitas, menutupi biaya operasional, dan biaya pengembangan Pesantren tanpa bantuan dari pihak luar. Hal ini tidak lepas dari peranan Koperasi dalam membantu berbagai hal yang 
Fadhilah, et al/Jurnal Ekonomi Syariah Teori dan Terapan Vol. 6 No. 2 Februari 2019: 305-318; IMPLEMENTASI PERAN KOPERASI DALAM PEMBERDAYAAN DAN KEMANDIRIAN PONDOK (STUDI KASUS PADA PONDOK PESANTREN MUKMIN MANDIRI SIDOARJO)

bersangkutan dengan pengembangan Pesantren.

\section{KESIMPULAN DAN SARAN}

\section{KESIMPULAN}

1. Koperasi Mukmin Mandiri berperan dalam meningkatkan pemberdayaan masyarakat Pesantren karena sudah mampu memberdayakan masyarakat Pesantren dalam berbagai aspek melalui program-program yang sudah di lakukan.

2. Koperasi Mukmin Mandiri berperan besar dalam meningkatkan kemandirian Pesantren karena dengan sokongan dana dari Koperasi maka biaya-biaya operasional, pengembangan pesantren, sarana dan prasarana bisa tertutupi oleh dana yang sebagian besar diperoleh dari keuntungan Koperasi yang masuk dalam kas Pesantren.

3. Bentuk pemberdayaan yang dilakukan Koperasi Mukmin Mandiri yakni menjadikan Koperasi sebagai lapangan pekerjaan, pembelajaran kewirausahaan dan tempat para santri untuk menambah pendapatan (income).

\section{SARAN}

1. Setelah melakukan penelitian ini dan berdasarkan pembahasan serta kesimpulan yang peneliti jabarkan, timbul beberapa saran untuk beberapa pihak kedepannya, yakni :
2. Bagi Koperasi Mukmin Mandiri agar kedepannya bisa melakukan pemberdayaan bagi masyarakat sekitar pondok melalui programprogram pemberdayaan yang sudah dikaji dengan melihat potensi yang ada dalam masyarakat dan wilayah sekitar Pesantren.

3. Bagi Pondok Pesantren Mukmin Mandiri agar kedepannya bisa lebih giat mempromosikan Pesantren agar lebih banyak masyarakat yang tau tentang keberadaan Pondok Pesantren yang tidak hanya mengajarkan IImu agama tetapi juga ilmu kewirausahaan ini.

4. Bagi Pemerintah atau dinas terkait agar bisa lebih mengembangkan lagi lembaga seperti Pesantren ini karena dengan berkembangnya lembaga-lembaga seperti ini dapat meningkatkan perekonomian di dalam lembaga dan juga sekitarnya.

\section{DAFTAR PUSTAKA}

Azyumardi, A. 1997. Pesantren, Kontinuitas, dan Perubahan Dalam Bilik-Bilik Pesantren: Sebuah Potret Perjalanan. Jakarta: Paramadina. Bakhri, Mokh. Syaiful. 2011. Sukses Ekonomi Syariah Di Pesantren: Belajar dari Kopontren Sidogiri, Koperasi BMT $M M U$, Sidogiri dan Koperasi BMT UGT Sidogiri. Pasuruan : Penerbit Cipta. 
Fadhilah, et al/Jurnal Ekonomi Syariah Teori dan Terapan Vol. 6 No. 2 Februari 2019: 305-318; IMPLEMENTASI PERAN KOPERASI DALAM PEMBERDAYAAN DAN KEMANDIRIAN PONDOK (STUDI KASUS PADA PONDOK PESANTREN MUKMIN MANDIRI SIDOARJO)

Blanchard, K, PC John dan R. Alan. 1998. Pemberdayaan Memerlukan Waktu Lebih Dari Semenit (terjemahan oleh Zoelkifli Kasip) Jakarta: Interaksa

Burhanudin. 2010. Prosedur Mudah Mendirikan Koperasi. Yogyakarta: Pustaka Yustisia

Djumransjah, H. M. 2001. Pendidikan Pesantren dan Kemandirian Santri. Jurnal IImi Pendidikan, Jilid 8, Nomor 2

Hutomo, Mardi Yatmo. 2000. Pemberdayaan Masyarakat dalam Bidang Ekonomi: Tinjauan Teoritik dan Implementasi. Jakarta : Bappenas.

Kartasasmita, Ginandjar, Ekonomi Rakyat: Memadukan Pertumbuhan dan Pemerataan; Jakarta: CIDES, 1995.

Madjid, Nurcholish. 2009. Bilik-Bilik Pesantren. Jakarta: Paramadina

Mastuhu. 1994. Dinamika Sistem Pendidikan Pesantren: Suatu Kajian Tentang Unsur dan Nilai Sistem Pendidikan Pesantren. Jakarta: INIS Maulana, Mirza, Al-Kautasari. 2014. Pemberdayaan Masyarakat Berbasis Pondok Pesantren (Studi Pondok Pesantren ASWAJA Lintang Songo Desa Sitimulyo, Piyungan, Bantul). Skripsi. Fakultas Dakwah Dan Komunikasi Universitas Islam Sunan Kalijaga.

Megarani, R. R. S. 2010. Strategi Pemberdayaan Santri di Pondok Pesantren Hidayatullah Donoharjo Ngaglik Sleman Yogyakarta. Skripsi.
Fakultas Dakwah. Universitas Islam Negeri Sunan Kalijaga Yogyakarta Moleong, Lexy J. 2017. Metodologi Penelititan Kualitatif. Bandung: Remaja Rosda Karya

Muhakamurrohman, A. 2014. Pesantren: Santri, Kiai, dan Tradisi. Jurnal Kebudayaan Islam. Vol. 12 (2), JuliDesember. 109-118

Muhammad. 2007. Lembaga Ekonomi Syariah. Yogyakarta: Graha Ilmu

Muttaqin, R. 2011. Kemandirian dan Pemberdayaan Ekonomi Berbasis Pesantren. Jurnal Ekonomi Syariah Indonesia. Vol. 1 (2): 65-94.

Qomar, Mujamil. Pesantren Dari Transformasi Metodologi Menuju Demokrasi Institusi, Jakarta Erlangga, 2006

Qomar, Mujamil. Pesantren Dari Transformasi Metodologi Menuju Demokrasi Institusi, Jakarta Erlangga, 2008

Rahmat, Ginanjar. 2014. Pemberdayaan Masyarakat Sebagai Bagian Dari Pembangunan Ekonomi Lokal. Skripsi. Departemen IImu Kesejahteraan Sosial, Universitas Indonesia Depok Jakarta

Rosyidi, S. (2006). Pengantar Teori Ekonomi: Pendekatan Kepada Teori Ekonomi Mikro dan Makro. Raja Grafindo Persada, Jakarta.

Sabiq, As-Sayyid. 1993. Fiqh As-Sunnah. Beirut: Dar al-Kitab al-Araby

Sanin. 2008. Eksistensi Koperasi di dalam Pembangunan dan Pengembangan Pesantren (Studi 
Fadhilah, et al/Jurnal Ekonomi Syariah Teori dan Terapan Vol. 6 No. 2 Februari 2019: 305-318; IMPLEMENTASI PERAN KOPERASI DALAM PEMBERDAYAAN DAN KEMANDIRIAN PONDOK (STUDI KASUS PADA PONDOK PESANTREN MUKMIN MANDIRI SIDOARJO)

Kasus di Pondok Pesantren An-Nur II Bululawang Malang). Skripsi. Jurusan IImu Pendidikan Sosial, Fakultas Tarbiyah.

Shihab, Quraish. 2002. Tafsir Al-Mishbah. Jakarta: Lentera Hati

Solichin, M.M. (2012). Kemandirian Pesantren di Era Reformasi. Jurnal Nuansa, Vol. 9, No. 1, Januari - Juni 2012.

Subagyo, Ahmad. 2015. Manajmeen Operasi Lembaga Keuangan Mikro Syariah. Jakarta: Mitra Wacana Media

Sudjarmoko, Bedy. 2013. Identifikasi Faktor Penentu Dalam Peningkatan Adopsi Benih Unggul Kakao Oleh Petani. Jurnal TDIP 2(3), 123-132

Sugiyono. 2012. Memahami Penelitian Kualitatif. Bandung: Alfabeta Suhendi, Hendi. 2002. Fiqh Muammalah. Jakarta: PT Raja Grafindo

Sumodiningrat, Gunawan. Membangun Perekonomian Rakyat, (Yogyakarta: Pustaka Pelajar 1998). Sutrisno, Edi. 2009. Manajemen Sumber Daya Manusia (Edisi Pertama). Jakarta: Kencana Prenada Media Group

Walsh, M. 2002. Pondok Pesantren dan Ajaran Golongan Islam Ekstrim: Studi Kasus di Pondok Pesantren Modern Putri 'Darur Ridwan' Parangharjo, Banyuwangi Jawa Timur. ACICIS Program Fakultas IImu Sosial dan Politik. Malang: Universitas Muhammadiyah Malang
Yin, Robert K. 2015. Studi Kasus : Desain dan Metode. Jakarta: Raja Grafindo Persada.

Yusuf, C. dan Suwito, NS (2009). Model Pengembangan Ekonomi Pesantren. Purwokerto: STAIN Press

Zuhriy, M. Syaifuddien. 2011. Budaya Pesantren dan Pendidikan Karakter Pada Pondok Pesantren Salaf. Walisongo, Vol.19 No.2 